\section{Амплитудный ВОЛОКОННО-ОПТИЧЕСКИЙ}

\section{ДАТЧИК ВИБРАЦИИ}

\author{
О. В. Бурдышева', И. Л. Никулин', www.pstu.ru \\ 'Пермский национальный исследовательский поли- \\ технический университет, Пермь, Россия
}

\begin{abstract}
Волоконно-оптические датчики вибрации имеют ряд неоспоримых преимуществ перед электрическими датчиками при работе рядом с действующими электрогенераторами или в условиях повышенной взрывобезопасности. Принцип работы амплитудного волоконнооптического датчика вибрации основан на нарушении закона полного внутреннего отражения. В статье описана концепция датчика вибрации, приведены результаты экспериментальных исследований прототипа.
\end{abstract}

\section{ВВЕДЕНИЕ}

Датчики вибрации необходимы для определения наличия опасного уровня вибрации при сейсмо-мониторинге шахтных и горных выработок, мониторинге строящихся и готовых объектов и объектов транспортной инфраструктуры. Применение электрических датчиков не всегда возможно из-за наличия электромагнитных полей, например около действующих электрогенераторов, или требований к пожаро- и особенно взрывобезопасности.

Материал волоконно-оптических датчиков (ВОД) представляет собой диэлектрик. ВОД не требуют электрического питания и заземле ния [1], следовательно, могут использоваться во взрывоопасных средах без риска возникно вения электрической искры; обладают хорошими показателями точности и производительности; могут обладать малым размером (до 0,1 см $^{2}$ для брэгговского чувствительного элемента); обладают низкой стоимостью; могут быть размещены на значительно удаленном расстоянии от регистрирующего оборудования.

Амплитудная модуляция оптического сигнала в предложенном датчике происходит с помощью нарушения полного внутреннего отражения с помощью изгиба.

\section{AMPLITUDE FIBER-OPTIC VIBRATION SENSOR}

\author{
O. V. Burdysheva', I. L. Nikulin', www.pstu.ru \\ 'Perm National Research Polytechnic University, Perm, \\ Ruusia
}

Fiber-optic vibration sensors have a number of indisputable advantages over electrical sensors when working close to existing power generators or in high explosion-proof conditions. The principle of operation of the amplitude fiber optic vibration sensor is based on the violation of the law of total internal reflection. The article deals with the concept of a vibration sensor, describing the results of experimental studies of the prototype.

\section{INTRODUCTION}

Vibration sensors are required to determine the presence of a dangerous level of vibration during seismic monitoring of mine and mine openings, monitoring of construction sites and finished facilities and transport infrastructure facilities. The use of electrical sensors is not always possible due to the presence of electromagnetic fields, e.g., near existing electrical generators, or fire and especially explosion-proof requirements.

The material of fiber-optic sensors (FOS) is a dielectric. FOSs do not require electrical power and grounding [1], therefore they can be used in explosive environments without the risk of an electric spark; they offer good accuracy and performance; they may have a small size (up to $0.1 \mathrm{~cm}^{2}$ for a Bragg sensor); they have low cost, with the possibility to be placed at a far distance from the recording equipment.

Amplitude modulation of the optical signal in the proposed sensor occurs through the violation of total internal reflection by bending.

Amplitude sensors, as a rule, are small in size, since their sensitive element can be a mechanical device that is specially inserted into the rupture of the fiber line or a section of the optical fiber with a mechanically formed microbend region.

In FOS on bending of a fiber, a change in external factors leads to a change in sensor parameters. Depending on the design of the sensing element, these changes lead either to periodic bending of the fiber (bends can be divided into micro- and macrobends) or to a decrease in the diameter of the bent 
Амплитудные датчики, как правило, имеют малые размеры, поскольку их чувствительный элемент может представлять собой специально введенное в разрыв волоконной линии перекрывающее световой поток механическое устройство или участок световода с механически образованной областью микроизгибов.

В ВОД на изгибе волокна изменение внешних факторов приводит к изменению параметров датчиков. В зависимости от конструкции чувствительного элемента эти изменения ведут либо к периодическому изгибанию волокна (изгибы можно разделить на микро- и макроизгибы), либо к уменьшению диаметра изогнутого световода, что приводит к дополнительным потерям мощности излучения.

Модулятор на основе изогнутого световода применим для работы на частотах до нескольких килогерц, что достаточно для измерения вибрации, возникающей, например, при вращении двигателей (1500 об/мин = 25 Гц). В датчиках такого типа могут быть использованы обычные волоконные световоды, однако для получения более высокой чувствительности необходимо конструировать специальные световоды.

При изгибе оптического волокна по малому радиусу нарушается условие полного внутреннего отражения, вследствие чего излучение из сердцевины выходит в оболочку волокна, распространяется по ней или рассеивается в окружающее пространство. Тогда падает мощность проходящего сигнала. Выделяют две причины таких потерь [1]:

- смещение модового пятна от оси волокна в начале изгиба;

- в изогнутом волокне периферийная часть моды распространяется со скоростью, превышающей скорость света в оболочке. Эта часть моды излучается в оболочку и теряется.

Величина потерь мощности, вызванных первой причиной, зависит только от радиуса кривизны волокна, а второй - от радиуса кривизны и протяженности изогнутого участка.

В работе [2] рассмотрены различные вопросы, связанные с существованием в волоконных световодах мод, распространяющихся в оболочке. Представлены точечные и приближенные методы расчета профилей распределения оболочечных мод. В работе [3] представлены зависимости потерь на микро- и макроизгибе. Метод микроизгибов был использован при fiber, which leads to additional losses of radiation power.

A modulator based on a curved fiber is applicable for operation at frequencies up to several kilohertz, which is enough to measure the vibration that occurs, e.g., when the motors rotate $(1500 \mathrm{rpm}=$ $25 \mathrm{~Hz}$ ). In sensors of this type, conventional optical fibers can be used; however, to obtain a higher sensitivity, it is necessary to design special optical fibers.

When an optical fiber bends along a small radius, the condition of total internal reflection is violated, as a result of which radiation from the core enters the fiber cladding, propagates through it, or scatters into the surrounding space. Then the power of the transmitted signal drops. There are two reasons for such losses [1]:

- displacement of the mode spot from the fiber axis at the beginning of the bend;

- in a bent fiber, the peripheral part of the mode propagates at a speed exceeding the speed of light in the cladding. This part of the mode is radiated into the cladding and is lost.

The magnitude of the power loss caused by the first cause depends only on the radius of curvature of the fiber, and the second on the radius of curvature and the length of the bent portion.

In [2], various issues related to the existence of modes propagating in a cladding in optical fibers were considered. Point and approximate methods for calculating the distribution profiles of cladding modes are introduced. In [3], the dependences of losses on micro- and macrobends are introduced. The microbend method was used in the construction of position, force, pressure, mechanical stress, acceleration, and vibration sensors. This group of sensors also includes a fiberoptic accelerometer [4]. An example of a FOS on macrobending is a fiber-optic device for measuring the refractive index [5].

The purpose of this work was the development and quality control of the vibration sensor.

\section{CONCEPT OF AMPLITUDE FIBER-OPTIC VIBRATION SENSOR}

The developed vibration sensor, is a point amplitude fiber-optic sensor. Its functioning is based on the violation of the law of total internal reflection. The sensing element is a section of the optical fiber, made in the form of a loop (4) attached to the base of the sensor body (2). The housing, in turn, is attached to the controlled surface. The weight (3) 
построении сенсоров положения, силы, давления, механического напряжения, ускорения и вибрации. К данной группе датчиков также относится волоконно-оптический акселерометр [4]. Примером ВОД на макроизгибе является волоконно-оптическое устройство измерения показателя преломления [5].

Целью настоящей работы стала разработка и качественная проверка датчика вибрации.

\section{КОНЦЕПЦИЯ АМПЛИТУДНОГО ВОЛОКОННО-ОПТИЧЕСКОГО ДАТЧИКА ВИБРАЦИИ}

Разработанный датчик вибрации является точечным амплитудным волоконно-оптическим датчиком. Его работа основана на нару шении закона полного внутреннего отражения. Чувствительный элемент представляет собой участок волоконного световода, выполненный в виде петли (4), закрепленной на основании корпуса датчика (2). Корпус в свою очередь крепится к контролируемой поверхности. На петле ОВ закреплен груз (3) (рис. 1). Вдоль чувствительного волокна установлены бортики (5) для гашения горизонтальных колебаний.

Принцип работы устройства заключается в следующем: излучение от источника направляют к чувствительному элементу по волокну 1 , устойчивому к изгибам. Наличие вибрации вызывает вертикальные колебания груза, что, в свою очередь, приводит к изменению диаметра изогнутого волокна (рис. 2). Часть излучения, проходящего через изогнутое волокно 4, покидает световод из-за нарушения полного внутреннего отражения. Следовательно, растут потери мощности излучения, проходящего сквозь чувствительный элемент. Излучение распространяется далее по световоду и попадает на фотоприемник.

Для измерения потерь мощности была создана экспериментальная установка (рис. За). Блок-схема установки (рис. 3б) включает в себя источник излучения (Л) - лазер Thorlabs SFL1550S (лазерный диод с внешним резонатором, рабо чая длина волны $\lambda=1550 \mathrm{Hм}, \mathrm{P}=40 \mathrm{MBT}$, корпус: Butterfly, одномодовое оптоволокно, FC/APCразъем, Thorlabs); чувствительный элемент (ЧЭ) - реализованный из оптического волокна Corning SMF-28 Ultra в виде петли с диаметром 18 мм; груз массой 70 мг; измеритель оптиче ской мощности (ФП) - Thorlabs РМ-200 (фотоприемник S146C (InGaAs), диапазон измеряемой оптической мощности 10 мкВт - 20 Вт); персо-

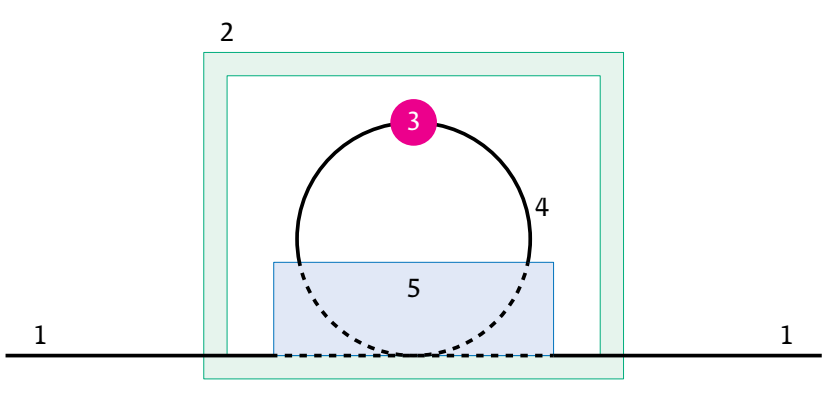

Puc. 1. Конструкция чувствительного элемента: 1 - оптическое волокно, подводящее / отводящее излучение, 2 - корпус датчика, 3- груз, 4- изогнутое волокно, 5- бортики Fig. 1. Design of the sensing element: 1 - optical fiber, input / output radiation, 2 - sensor housing, 3-weight, 4 bent fiber, 5 - breakers

is fixed on the loop of the optical fiber (Fig. 1). The breakers (5) are installed along the sensitive fiber to dampen horizontal vibrations.

The principle of operation of the device is as follows. Radiation from the source is fed to a sensitive element along fiber 1 , resistant to bends. The presence of vibration causes vertical oscillations of the load, which in its turn, leads to a change in the diameter of the bent fiber (Fig. 2). Part of the radiation passing through the curved fiber 4 leaves the fiber due to the violation of total internal reflection. Therefore, the power losses of the radiation passing through the sensing element

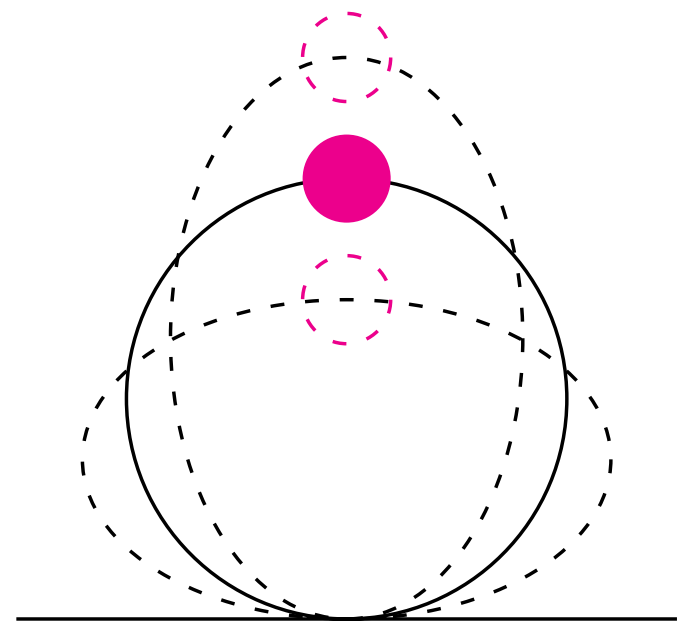

Puc. 2. Деформация волокна при колебаниях грузика, закрепленного на ОВ

Fig. 2. Deformation of the fiber caused by the oscillation of the weight attached to the OF 
нальный компьютер (ПК) и источник вибрации (ИВ) - портативная звуковая колонка.

Реализован автоматизированный сбор данных с предложенного датчика вибрации с помощью разработанного программного обеспечения для фотоприемника с последующей программной обработкой.

Для проверки работоспособности предложенной конструкции датчика изучена динамика изменения мощности во время действия источника вибрации, результаты представлены на рис. 4. Из графика видно, что средняя мощность проходящего излучения при воздействии вибрации изменяется на $\Delta P$, и появляется разброс величины мощности $\delta$. Пики во время действия вибрации вызваны переключением звукового файла на начало. После прекращения действия вибрации значение величины мощности возвращается к прежнему значению.

Зависимости изменения мощности от амплитуды показаны на рис. 5. Анализируя график, можно обнаружить, что экспериментальные линии, полученные при повторении условий эксперимента, накладываются друг на друга, то есть результаты повторимы, и наблюдается явная зависимость изменения величины мощнсти от изменения амплитуды колебаний.

Оптическое волокно (ОВ) было исследовано на наличие микротрещин в момент, предшествующий проведению серии экспериментов. А затем такое исследование повторили после проведения экспериментов. При этом ОВ исследовали после его использования в течение 60 мин и после его использования в течение месяца. Во время эксплуатации в оптическом волокне чувствительного элемента появляются микротрещины. Однако необходимо отметить, что это не сказывается на работоспособности датчика, так как при длительном использовании ОВ чувствительный элемент в процессе эксплуатации не выходит из строя. Очевидно, что срок эксплуатации конкретного чэ будет зависеть от внешних условий, амплитуды вибрации и типа применяемого волокна.

В ходе проведенных экспериментов установлено, что созданный датчик вибрации и система измерений регистрируют вибрацию, дают повторяемые результаты, и Чэ не выходит из строя в процессе эксплуатации. Таким образом, предложенная конструкция подтвердила свою работоспособность.

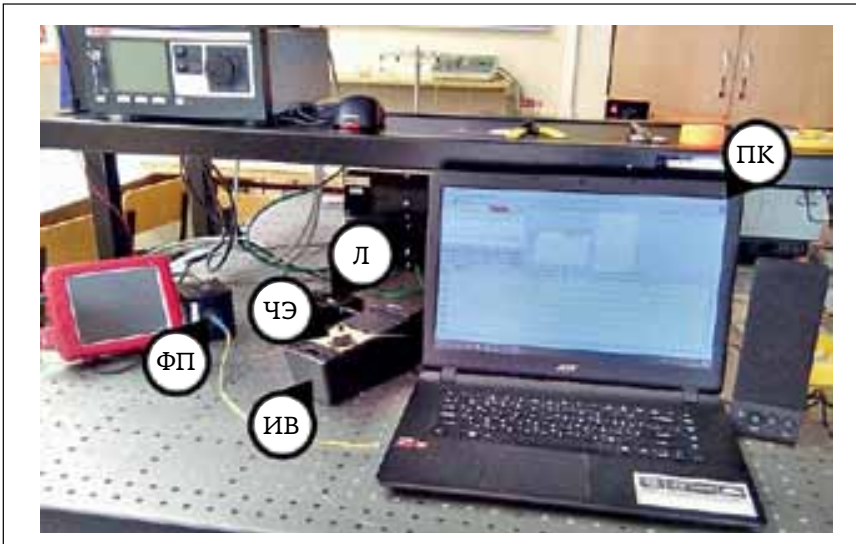

a)

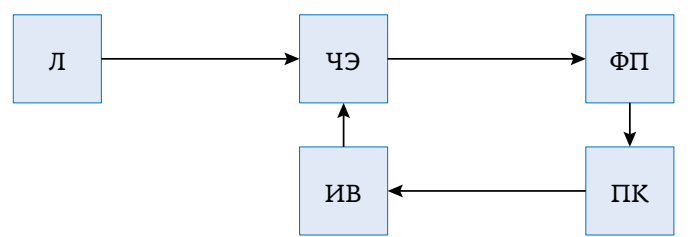

b)

Puс. 3. Экспериментальная установка: а) техническая реапизация; b) принципиальная схема (Л - лазер, чЭ- чувствительный элемент, ФП-фотоприемник, ИВ - источник вибрации, ПК - персональный компьютер)

Fig. 3. Experimental set-up: a) technical implementation; b) schematic diagram ( $L$-laser, SE - sensitive element, PD - photodetector, VS - source of vibration, PC - personal computer)

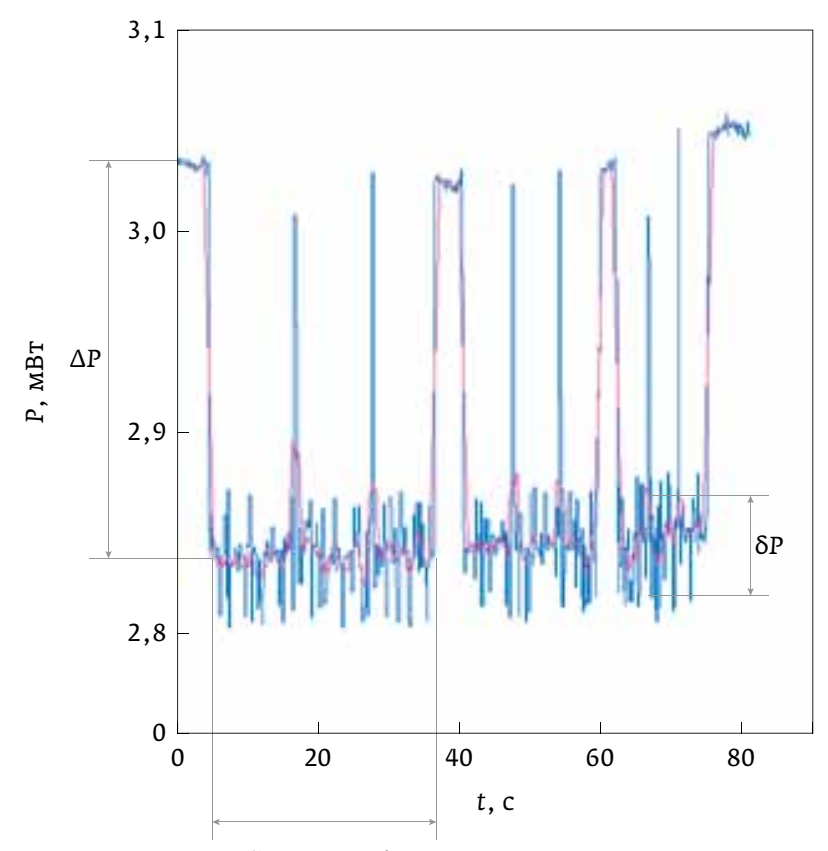

Воздействие вибрации

Puс. 4. Динамика изменения мощности во время работы датчика

Fig. 4. Dynamics of power change during the sensor operation. 


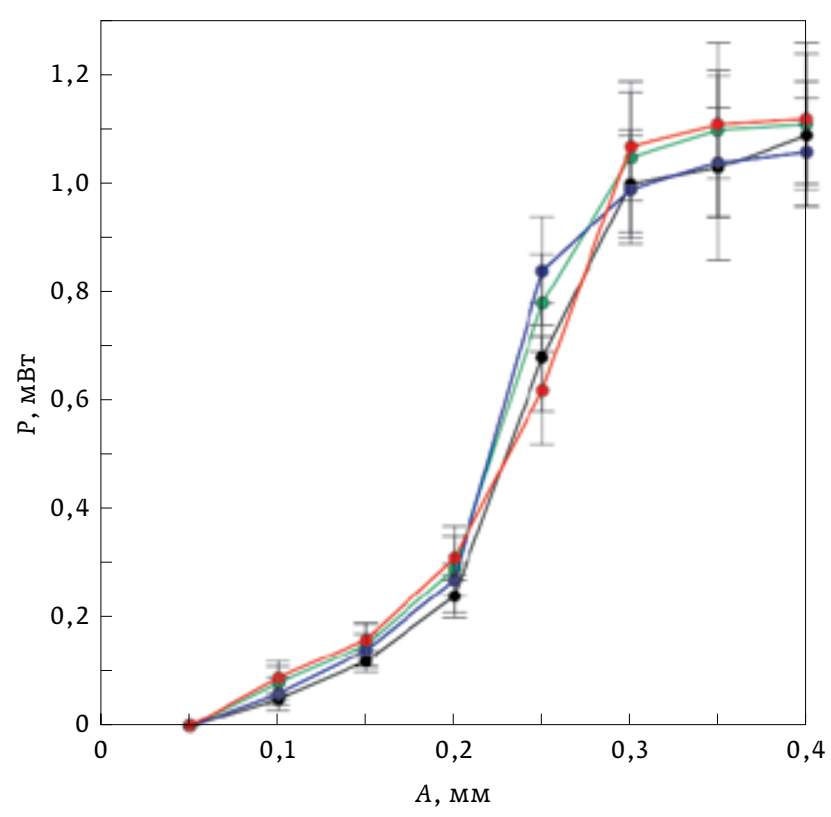

Puc. 5. Зависимости падения мощности $\triangle P$ от амплитуды колебаний при частоте 80 Ги, (кривые соответствуют разным сериям экспериментов)

Fig. 5. Dependencies of power drop $\triangle$ P on the amplitude of oscillations at a frequency of $80 \mathrm{~Hz}$, (curves correspond to different series of experiments)

Оценку чувствительности датчика можно провести по данным, представленным на рис. 5. При амплитуде вибрации $\mathrm{A} \approx 1$ мм и частоте $f=80$ Гц виброускорение $a_{B}=A(2 \pi f)^{2}=25 g$, где $g-$ ускорение свободного падения. Изменение мощноности $\Delta \mathrm{P}_{0,1}$ при амплитуде 0,1 мм соответствует виброускорению 2,5g, при 0,3 мм-7,5g. Чувствительность амплитудного датчика в этом случае $\left(\mathrm{DP}_{0,3}-\mathrm{DP}_{0,1}\right) / \Delta a_{8}=0,18 \mathrm{MBT} / g$.

\section{ЗАКЛЮЧЕНИЕ}

Создано устройство, которое позволяет вести непрерывную регистрацию вибраций контролируемого объекта. Датчик исключает необходимость предварительной настройки рабочей точки перед эксплуатацией устройства. Таким образом, расширяется арсенал технических средств регистрации вибраций. Отличительной особенностью и возможным преимуществом перед пьезоэлектрическими датчиками является возможность работы ЧЭ при больших (до нескольких десятков сантиметров) амплитудах вибрации. increase. The radiation propagates further through the fiber and hits the photodetector.

An experimental installation was implemented to measure power losses (Fig. 3. a). The flowchart of the setup (Fig. 3.b) includes a radiation source (L), Thorlabs SFL1550S laser with an operational wavelength of $1550 \mathrm{~nm}$; sensitive element (SE), implemented from Corning SMF-28 Ultra optical fiber in the form of a loop with a diameter of $18 \mathrm{~mm}$; a weight with a mass of $70 \mathrm{mg}$; photodetector (PD), Thorlabs RM-200 (S146C (InGaAs), $\Delta \mathrm{P}=10 \mu \mathrm{W}-20 \mathrm{~W}$ ); personal computer (PC) and source of vibration (VS), portable speaker.

The automated data collection from the proposed vibration sensor was implemented using the developed software for the photodetector with the subsequent software processing.

To test the performance of the proposed sensor design, the dynamics of changes in power during the action of the vibration source were studied, the results are shown in Fig. 4. It can be seen from the plot that the average power of the transmitted radiation under the influence of vibration changes by $\Delta P$, and a variation of the magnitude of power $\delta P$ appears. Peaks during vibration are caused by switching the sound file to the beginning. After the vibration is stopped, the value of the power value returns to the previous value.

The dependences of the power change on the amplitude are shown in Fig.5. Analyzing the plot, it can be found that the experimental lines obtained by repeating the experimental conditions overlap each other, i.e., the results are consistent and change in magnitude of the power clearly depends on the change in the amplitude of oscillations.

An optical fiber (OF) was examined for the presence of microcracks at the time preceding the series of experiments. Then, this study was repeated after the experiments. In this case, the $\mathrm{OF}$ was examined after its use for 60 minutes and after its use for a month. During operation, microcracks appear in the optical fiber of the sensing element. However, it should be noted that this does not affect the performance of the sensor, since with prolonged use of the $\mathrm{OF}$, the sensitive element does not fail during operation. Obviously, the life of a particular SE will depend on the external conditions, the amplitude of vibration and the type of fiber used.

In the course of the experiments carried out, it was established that the created vibration sensor and the measurement system register the vibration, deliver consistent results, and the SE does not fail 
На данный момент создан прототип ВОД вибрации, проведены лабораторные испытания в диапазоне частот колебаний 5-100 Гц, амплитуд колебаний 1-100 мм, чувствительность датчика составила 0,18 мВт/g. На предложенную конструкцию датчика получен патент [6].

Использование датчика в системах измерения уровня вибрации позволяет развивать разработки измерительных систем в следующих направлениях: совершенствование ЧЭ; разработка оптоэлектронного устройства, обеспечивающего ввод/вывод стабилизированного излучения и обработку (усиление и интегрирование); совершенствование ПО; планирование измерений уровня вибрации на моделях строительных объектов и на натуральных объектах строительства.

\section{СПИСОК ЛИТЕРАТУРЫ}

1. Бурдышева О. В. и др. Разработка волоконно-оптического датчика показателя преломления на макроизгибе. Вестник современной науки. 2015; 5: 18-21.

Burdysheva O. V. et al Razrabotka volokonno-opticheskogo datchika pokazatelya prelomleniya na makroizgibe. Vestnik sovremennoj nauki. 2015; 5: 18-21

2. Иванов О. В., Никитов С.А., Гуляев Ю. В. Оболочечные моды волоконных световодов, их свойства и применение. Успехи физических наук. 2006; 176(2): 175-202.

Ivanov O. V., Nikitov S. A., Gulyaev Yu. V Obolochechnye mody volokonnyh svetovodov, ih svojstva i primenenie. Uspekhi fizicheskih nauk. 2006; 176(2): 175-202.

3. Оразымбетова А. К. Исспедование вибрационных и температурных воздействий на функциональные свойства световода URL: [http://docplayer.ru/31203773-Orazymbetova-aygulkanybekovna.html].

Orazymbetova A. K. Issledovanie vibracionnyh i temperaturnyh vozdejstvij na funkcional'nye svojstva svetovoda. URL: http:// docplayer.ru/31203773-Orazymbetova-aygul-kanybekovna.html].

4. Patent RU132564 / Fiber optic accelerometer; Kulchin Yu.N., Vitrik O.B, Gurbatov S. O.; 2013

5. Patent RU169126 / Fiber optic refractive index measurement device; Burdysheva O.V., Sushko D.N., Sholgin E. S. et al; 2017.

6. Patent RU179547 / Fiber optic vibration recorder. Nikulin I. L., Burdysheva O. V.; 2018. during operation. Thus, the proposed design has confirmed its performance.

The sensitivity of the sensor can be estimated using the data shown in Fig. 5. With the vibration amplitude $A \approx 1 \mathrm{~mm}$ and the frequency $f=8080 \mathrm{~Hz}$, the vibration acceleration is $a_{B}=A(2 \pi f)^{2}=25 \mathrm{~g}$, where $g$ is the acceleration of gravity. The change in power $\Delta \mathrm{P}_{0.1}$ with an amplitude of $0.1 \mathrm{~mm}$ corresponds to a vibration acceleration of $2.5 \mathrm{~g}$, with $0.3 \mathrm{~mm}-7.5 \mathrm{~g}$. The sensitivity of the amplitude sensor in this case $\left(\Delta \mathrm{P}_{0.3}-\mathrm{P}_{0.1}\right) / \Delta a_{\mathrm{B}}=0.18 \mathrm{~mW} / \mathrm{g}$.

\section{CONCLUSION}

A device has been created that allows continuous recording of vibrations of the controlled object. The sensor eliminates the need to pre-set the operating point before operating the device. Thus, the arsenal of technical means for registering vibrations is expanding. A distinctive feature and a possible advantage over piezoelectric sensors, is the possibility of operating the SE with large (up to several tens of centimeters) vibration amplitudes.

Currently, a prototype FOS of vibration has been created, laboratory tests have been conducted in the range of vibration frequencies $5-100 \mathrm{~Hz}$, vibration amplitudes $1-100 \mathrm{~mm}$, the sensor sensitivity has been $0.18 \mathrm{~mW} / \mathrm{g}$. A patent has been obtained for the proposed sensor design [6].

The use of the sensor in the systems for measuring the level of vibration makes it possible to evolve the development of measuring systems in the following directions: the improvement of the SE; the development of an optoelectronic device providing input / output of stabilized radiation and processing (amplification and integration); the software improvements; the planning of vibration level measurements on models of construction objects and on natural construction objects. 